\title{
Chromatin enrichment of histone marks H4Ac and H3K9me3 in TP53 gene domain in breast cells
}

\author{
G. C. Santos Jr'1 , A. C. S. Goes ${ }^{2}$, C. V. de Moura Gallo ${ }^{1}$ \\ ${ }^{1}$ Departament of Genetics, Institute of Bilogy, University of State of Rio de Janeiro (UERJ) \\ Rua Sao Francisco Xavier, 524, sala 525-6, Maracana, Rio de Janeiro, CEP, 20.550-013, Brazil \\ ${ }^{2}$ Department of Science and Biology, Institute of Bilogy, University of State of Rio de Janeiro (UERJ) \\ Rua Sao Francisco Xavier, 524, sala 525-6, Maracana, Rio de Janeiro, CEP, 20.550-013, Brazil \\ claudia.gallo@pq.cnpq.br
}

\begin{abstract}
In non-cancerous breast cell lines HB2 and MCF 10A the TP53 gene is localized inside a relatively small $\sim 50 \mathrm{~kb}$ loop domain delimited by two S/MARs. Aim. To analyze the chromatin markers H4Ac and H3K9me3 of these two S/MARs and of the TP53 gene P1 promoter in different breast cells lines. Methods. We used chromatin immunoprecipitation (ChIP) to characterize the chromatin status of these S/MARs elements in breast non-cancerous cell lines HB2 and MCF10A and cancerous MCF-7, MDA-MB-231, BT-474 and T47D cell lines, by chromatin enrichment of H4Ac and H3K9me3 epigenetic markers, hallmarks of open and closed chromatin, respectively. Results. We found that these chromatin epigenetic markers are differentially distributed in S/MARs for all analyzed breast cell lines. Conclusions. We found no correlation between S/MARs and chromatin epigenetic status, suggesting that nuclear matrix fixation and chromatin status can be independent. High enrichment of H3K9me3 in the TP53 gene P1 promoter region in MCF-7, could explain lower levels of the TP53 expression, described earlier by our group.
\end{abstract}

Keywords: TP53, loop domain, MAR, breast cancer, chromatin markers, ChIP assay.

Introduction. DNA in eukaryotic nucleus is organized in nucleosomes consisting of $\sim 147 \mathrm{bp}$ of DNA wrapped around an octamer of four core histone proteins (H2A, $\mathrm{H} 2 \mathrm{~B}, \mathrm{H} 3$ and $\mathrm{H} 4)$. The $\mathrm{N}$-terminal tail of histones is a subject to several types of post-translational modifications, the two most important of which are acetylation and methylation of some amino acids, usually lysine. These histone modifications can affect the chromatin assembly making it permissible for proteins to modulate cellular processes such as transcription, repair, replication and genome stability [1-4]. Histone acetylation and methylation are catalyzed by histone acetyltransferases (HATs) and histone methyltransferases (HMTs), respectively. Histone $\mathrm{H} 4$ acetylation (H4Ac) is a hallmark of open chromatin or euchromatin and may be a sign of gene activation [5-7]. It is generally decreased in breast cancer cell lines and tissues $[8,9]$. In contrast,

(c) Institute of Molecular Biology and Genetics, NAS of Ukraine, 2014 histone $\mathrm{H} 3$ lysine 9 trimethylation ( $\mathrm{H} 3 \mathrm{~K} 9 \mathrm{me} 3)$ is a hallmark of closed chromatin or constitutive heterochromatin and may denote gene repression $[10,11]$. Chromatin is further organized in DNA loop domains delimited by the border elements that include nuclear Scaffold/Matrix Attachment Regions (S/MARs), which could be 20 to $200 \mathrm{~kb}$ long $[12,13]$. The S/MARs are responsible for DNA attachment to the nuclear matrix (NM) and are linked to DNA replication and transcription. They may include Topoisomerase II binding sites [14, 15] as well as other sequence motifs. Furthermore, NM is enriched in several transcription factors, which have been suggested to be MAR binding proteins (MARBPs) [16-18].

Several factors potentially affect the association of DNA with the NM, including the DNA sequence itself and its epigenetic state [19-22]. Scaffold Attachment Regions (SARs) can be enriched in H4Ac [23]. The attachment of human S/MARs to the nuclear matrix de- 
pends on a high DNA methylation level and the absence of H3K9ac within S/MAR [24]. Interestingly, some histone modification enzymes such as HATs are associated with NM [25]. Additionally, the loops can be active or inactive due to the MARs chromatin enrichment in H4Ac or H3K9me3, respectively [26].

However, as nuclear matrix remains a controversial concept [13] and the data on the interplay between MARs and histone epigenetic chromatin status are still absent, we decided to test whether the association of $\mathrm{S} / \mathrm{MARs}$ with the nuclear matrix in breast cancer cell lines corresponds to specific chromatin modifications. We have previously mapped S/MARs in the $167 \mathrm{~kb}$ locus of the tumor suppressor gene TP53 in cancerous breast cell lines, MDA-MB-231, BT-474, T47D, MCF7 , and non-cancerous breast cell lines, MCF10A and HB2, using DNA arrays [27]. We found that the loop domain organization in these cell lines was quite variable. MAR2 and MAR3 were detected in non-cancerous cells HB2 and MCF10A, and MAR3 was detected in cancerous cells BT-474 and T47D. Interestingly, these MARs were symmetrically disposed in relation to the TP53 gene P1 promoter, probably constituting the borders of a chromatin loop. Now, in an attempt to check the chromatin accessibility of these two S/MARs and the TP53 gene P1 promoter region we evaluated the chromatin enrichment levels of the histone epigenetic markers H4Ac and H3K9me3 (linked to open and closed chromatin, respectively), by the chromatin immunoprecipitation (ChIP) assay, in the same breast cells lines. We found no correlation between the chromatin enrichment of histone epigenetic marks and nuclear matrix attachment regions. We believe that our results will help to get a better understanding on the TP53 chromatin domain organization and transcriptional control.

Materials and methods. Cell lines. All cell lines were obtained from David Cappellen and Nancy Hynes (Friedrich Miescher Institute for BioMedical Research, Novartis Research Foundation, Switzerland). The human mammary carcinoma cell lines MDA-MB-231 and T47D were cultured in DMEM medium supplemented with $10 \%$ bovine serum, $0.5 \%$ penicillin/streptomycin and $1 \%$ glutamine. The human mammary carcinoma cell lines MCF-7 and BT-474 were cultured in RPMI medium supplemented with $10 \%$ bovine serum, $0.5 \%$ peni- cillin/streptomycin and $1 \%$ glutamine. The control noncancerous epithelial cell lines MCF10A and HB2 were cultured in DMEM medium supplemented with $10 \%$ horse serum, $0.5 \mu \mathrm{g} / \mathrm{ml}$ hydrocortisone, $10 \mu \mathrm{g} / \mathrm{ml}$ insulin, $0.5 \%$ penicillin/streptomycin and $1 \%$ glutamine.

ChIP assay. $25 \cdot 10^{6}$ cells were cross-linked with $1 \%$ formaldehyde for $10 \mathrm{~min}$ in a rocking platform at room temperature. Cross-linking reaction was stopped with $0.125 \mathrm{M}$ Glycine diluted in $1 \times \mathrm{PBS}$. The cells were washed with ice-cold 1X PBS and resuspended in $1 \mathrm{ml} \mathrm{Ly-}$ sis/Sonication cold buffer ( $1 \%$ SDS, 10 mM EDTA and $50 \mathrm{mM}$ Tris- $\mathrm{HCl}, \mathrm{pH}$ 7.5) with fresh $0.5 \mathrm{mM}$ PMSF and $1 \times$ PIC (Protease Inhibitor Cocktail) and incubated for $30 \mathrm{~min}$ on ice. The lysates were homogenized with 10 strokes, centrifuged at $750 \mathrm{~g}$ for $5 \mathrm{~min}$ at $4{ }^{\circ} \mathrm{C}$ and the supernatant was discarded. The pellet was resuspended in $350 \mu \mathrm{l}$ of Lysis/Sonication cold buffer with freshly added $1 \mathrm{mM}$ PMSF and $1 \times$ PIC, sonicated on ice and centrifuged for $10 \mathrm{~min}$ with $2000 \mathrm{~g}$ at $4{ }^{\circ} \mathrm{C}$. The supernatant contains extracted chromatin. The immunoprecipitation was carried out overnight at $4{ }^{\circ} \mathrm{C}$ with constant agitation in an immunoprecipitation buffer ( $5 \mathrm{mM}$ Tris$\mathrm{HCl}, \mathrm{pH} 8.0,15 \mathrm{mM} \mathrm{NaCl}, 1 \mathrm{mM}$ EDTA and $0.1 \% \mathrm{NP}$ 40) with $20 \mu \mathrm{g}$ of chromatin, $750 \mu \mathrm{g}$ of Protein G dynabeads \#100.03D («Invitrogen ${ }^{\circledR} »$, USA), $4 \mu \mathrm{g}$ of antibodies H4 pan-acetyl (\#39243, «Active Motif $\left.{ }^{\mathbb{P}} »\right)$, trimethyl H3K9 (\#05-1242, «Millipore $\left.{ }^{\circledR} »\right)$, normal rabbit IgG (\#PP64B, «Millipore ${ }^{\circledR} »$; control) and $1 \times$ PIC. All the immunoprecipitations were made at 1:4 dilutions. The magnetic beads were washed 6 times with the immunoprecipitation buffer and the chromatin was eluted with the Lysis/sonication buffer for $15 \mathrm{~min}$ at room temperature with constant agitation.

The chromatin was eluted from magnetic beads and reversed cross-linked by $5.25 \times$ dilution with $0.2380 \mathrm{M}$ $\mathrm{NaCl}$, denatured at $95^{\circ} \mathrm{C}$ for $15 \mathrm{~min}$, after $1 \mu \mathrm{l}$ of RNAse A $(10 \mu \mathrm{g} / \mu \mathrm{l})$ was added and incubated at $37^{\circ} \mathrm{C}$ for 15 min and $1 \mu$ of proteinase $\mathrm{K}(10 \mu \mathrm{g} / \mu \mathrm{l})$ was added and incubated at $67^{\circ} \mathrm{C}$ for $15 \mathrm{~min}$. DNA was cleaned-up by the standard Phenol-Chloroform method and submitted to qPCR. qPCR, was carried out using the standard Syber-Green method with the Mastermix ( $\left(\operatorname{Roche}^{\mathbb{B}} »\right.$, France).

All fold enrichment values of $\mathrm{H} 4 \mathrm{Ac}$ and $\mathrm{H} 3 \mathrm{~K} 9 \mathrm{me} 3$ are relative to the fold enrichment values of the $\beta$-actin gene region or the alpha-satellite region, respectively. 

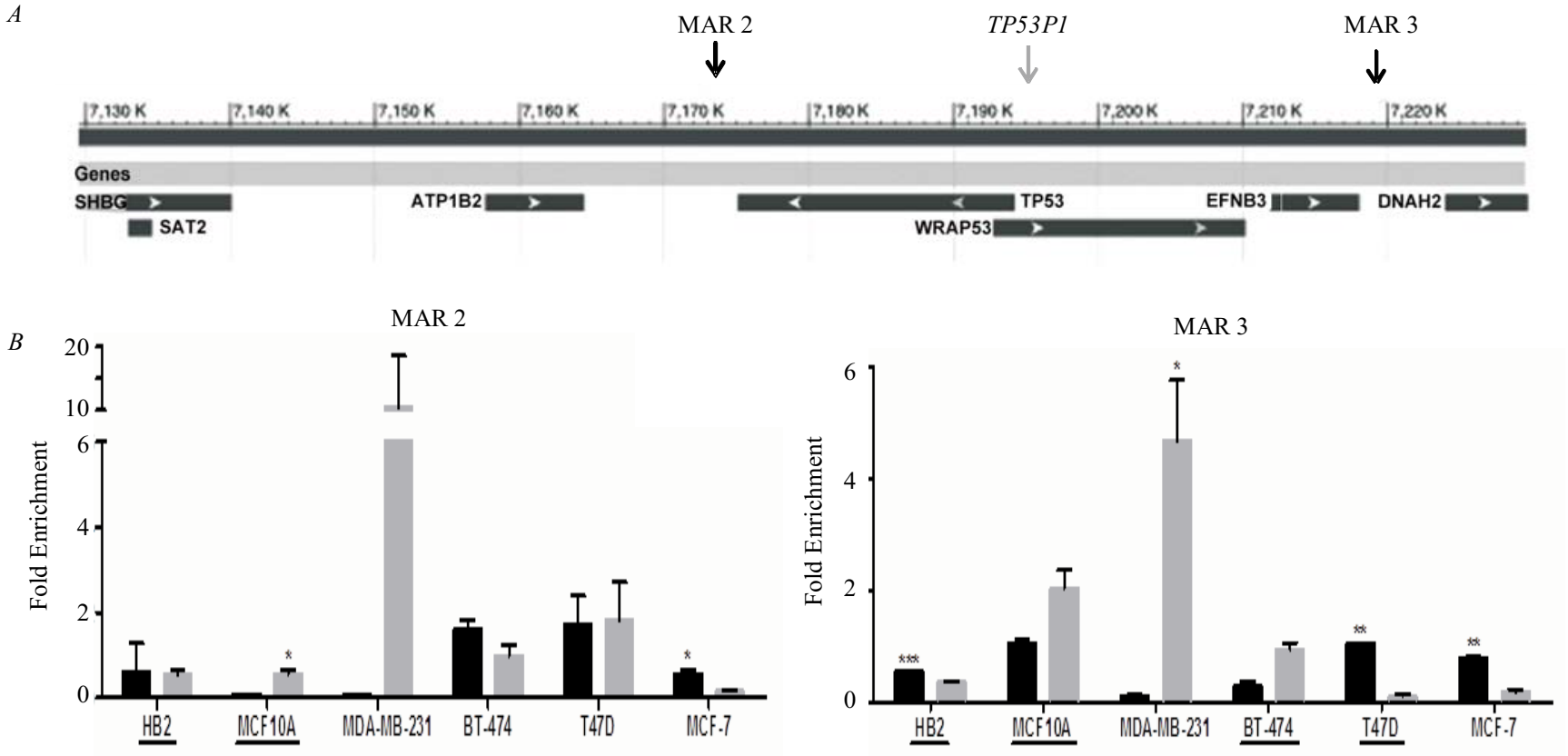

Fig. 1. Chromatin state of MARs in breast cell lines in TP53 domain: $A-T P 53$ genomic region organization based on NCBI database: NT_ 010718.16:7.1M-7.2M (94 kb+), covering the $167 \mathrm{~kb}$ genomic domain at the $17 \mathrm{p} 13.1$ chromosomal region (genes are represented by horizontal bars and arrows indicate the analyzed MARs - black; positions of MAR2 and MAR3 are indicated by black arrows, relatively to position 0, which corresponds to the major transcription start site (P1) of TP53 (TP53P1, indicated by a gray arrow); in the HB2 and MCF10A cell lines, MARs 2 and 3 delimitate a $50 \mathrm{~kb}$ loop encompassing the TP53, WRAP53 and EFNB3 genes); B - ChIP assay of MAR2 and MAR3, indicating the enrichment of euchromatin marker H4Ac (black column)(relative to beta-actin gene region) and heterochromatin marker H3K9me3 (grey column) (relative do alpha-satellite gene region); the cell lines utilized to describe MAR2 or MAR3 are underlined. Error bars correspond to +/-S.E.M. from 3 different experiments; ${ }^{*} \mathrm{p}<<0.05 ; * * \mathrm{p}<<0.005 ; * * \mathrm{p}<0.0001$

All primers, synthesized by SIGMA ${ }^{\circledR}$, are listed in $5^{\prime}-3^{\prime}$ and $\mathrm{F}$ - forward, $\mathrm{R}$ - reverse:

MAR2: F - CTGGCCGGAAATGTTTTCTA, R GTGCCAGGAGCTGTTCTAGG;

MAR3: F - GTCTGGAGCTATTTGAAAATG, R TGTCTTCCTGTGCCTGTAGTC;

TP53P1: F - GCGTGTCACCGTCGTGGAAAG, R - GGAGCCTCGCAGGGGTTGATG;

$\beta$-actin gene region: F - GACGTAGCACAGCT TCTCCT, R - GGGACCTGACTGACTACCTCAT; Alpha-Satellite (\#CS207313, Millipore ${ }^{\circledR}$ ) F - CTG CACTACCTGAAGAGGAC, R - GATGGTTCAAC ACTCTTACA.

All chromatin extraction, immunoprecipitation and qPCR were done in triplicate and the error bars corresponded to the S.E.M. of three different experiments.

Statistic analysis. All statistic data and graphics were performed by the GraphPad version 6.0 using unpaired $t$-test analyses with Welch's correction and $95 \%$ confidence interval.
Results and discussion. Association of S/MARs in breast cells is independent of $\mathrm{H} 4 \mathrm{Ac}$ and $\mathrm{H} 3 \mathrm{~K} 9 \mathrm{me} 3 \mathrm{en}$ richment levels. Scaffold/Matrix Attachment Regions (S/MARs) have been described as cis-acting factors involved in DNA replication, transcription regulation and chromatin organization. Possibly they take part in the coordination of these cellular processes [28-30]. The tumor suppressor gene TP53 is one of the most studied genes implicated in cancer and, despite a huge knowledge on its post-translational regulation [31, 32], its transcription control and genomic domain are not very well established [33]. In a previous work we described MARs in a genomic region of $167 \mathrm{~kb}$ containing the TP53 and neighboring genes, using different cell lines [27]. Here we concentrated our study on two MARs, namely MAR2 and MAR3.

Interestingly, the association of MAR2 with the nuclear matrix was detected only in two analyzed noncancerous cell lines HB2 and MCF10A where the TP53 gene is organized into $\mathrm{a} \sim 50 \mathrm{~kb}$ loop domain flanked 


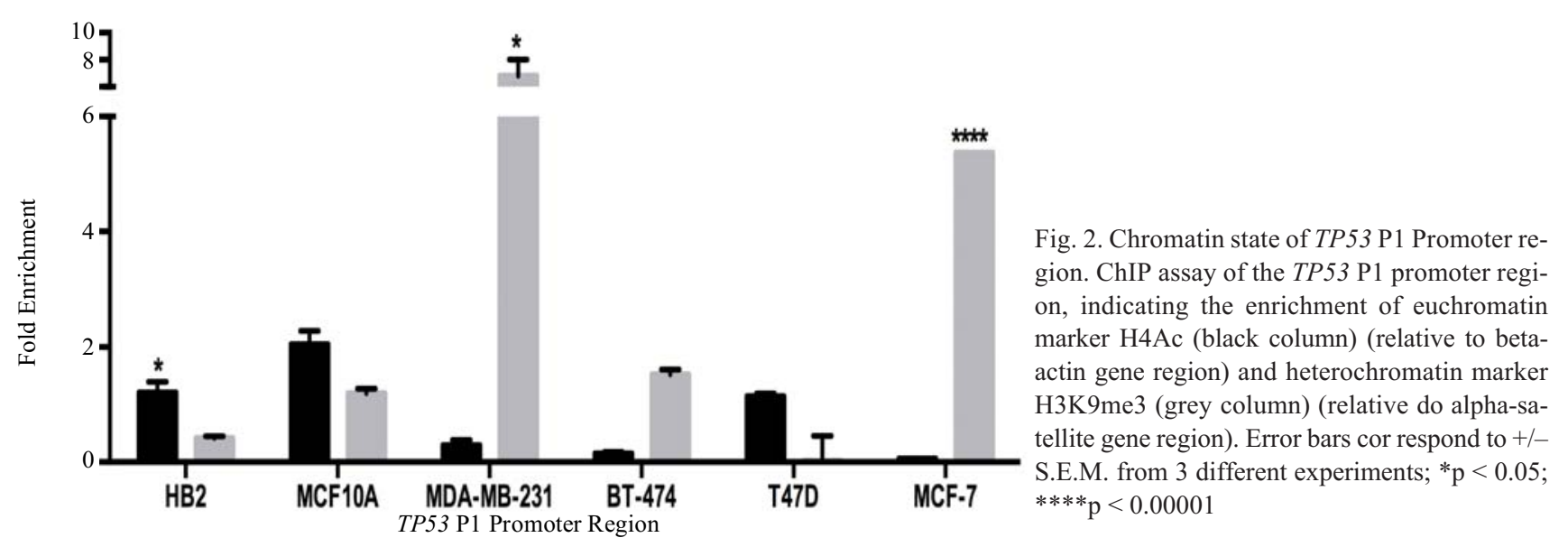

by two S/MARs (Fig. 1, $A$ ). This organization is perturbed in cancerous cell lines MDA-MB-231, BT-474, T47D and MCF-7 [27]. Chromatin is composed of DNA and proteins, mostly histones, which are involved in genomic DNA organization in the nuclei. Histone alterations in N-terminal tail by acetylation, methylation or ubiquitylation may produce different levels of DNA compaction, leading to an open chromatin or euchromatin, permissive to the protein factors access, or leading to close chromatin or heterochromatin, repressive for the association of transcription factors [34-37]. These histone alterations may be tracked using a ChIP assay, and give an idea of the chromatin ambiance through the epigenetic profile at a genomic site, in normal and cancerous cells $[38,39]$. In order to gain insight of the mechanisms governing the attachment of these two $\mathrm{S} /$ MARs, MAR2 and MAR3, in normal and breast cancer cell lines and to determine the chromatin state at $\mathrm{S} /$ MARs, we performed the ChIP assays to detect the enrichment of both $\mathrm{H} 4 \mathrm{Ac}$ and $\mathrm{H} 3 \mathrm{~K} 9$ me3 euchromatin and heterochromatin markers, respectively, in two noncancerous cell lines: HB2 and MCF10A, and in four cancerous cell lines: MCF-7, T47D, BT-474 and MDAMB-231 (Fig. 1, B). As presented in Fig. 1, B, we could not identify a specific pattern of the epigenetic histone markers enrichment in non-cancerous and cancerous cells, despite certain differences between histone mar kers when MAR3 are present in cancerous cells, BT474 and T47D.

Moreover, the histone enrichment levels were quite different among cell lines, suggesting that neither H4Ac nor H3K9me3, chromatin enrichments, are linked to S/MARs. Indeed, a link between the association of these regions to the NM and active histone marks remains controversial [13, 24, 40]. These results, suggest that nuclear matrix fixation and chromatin epigenetic status can be independent.

Chromatin status of TP53 gene P1 promoter can be linked to TP53 transcription in MCF-7 cells. We have simultaneously performed ChIP assays in the TP53 gene P1 promoter region (TP53P1) to detect chromatin changes associated with the TP53 transcriptional status (Fig. 2). Indeed, in the cell lines, TP53 is less expressed in cancerous cells, relative to HB2, as follows: $\sim 2.5 \mathrm{X}$ in $\mathrm{MCF}$ 7 and T47D, 1.66X in MDA-MB-231 and $\sim 1.11 \mathrm{X}$ in BT-474 [27]. Interestingly, a higher enrichment of heterochromatin marker H3K9me3 in TP53P1 in MCF-7, as shown in Fig. 2, corroborates the lowest level of the TP53 gene expression observed in this cell line. Also, a higher enrichment of H4Ac in the non-cancerous cell lines, MCF10A and HB2, corroborates higher levels of TP53 described in HB2, in our earlier report [27]. These results together suggest that chromatin status of the P1 TP53 promoter, can regulate the TP53 expression in some breast cell lines.

Conclusions. Our results show no correlation between S/MARs and $\mathrm{H} 4$ acetylation/H3K9 trimethylation, suggesting that nuclear matrix fixation and these specific chromatin modifications are possibly independent events during breast cancer progression. Also, chromatin status of the P1 TP53 promoter can regulate TP53 expression in the MCF-7 cell line.

Acknowledgements and funding. This research was supported by grants from CNPQ (INBEB-CNPQ grant N 57.3767/2008-4) and CAPES-COFECUB (grant N 615/2008). 
Збагачення хроматиновими маркерами Н4Ac i H3K9me3 домену гена TP53 у клітинних лініях молочної залози

Г. Дж. Р. Сантос, А. С. С. Хоес, К. В. де Моура Галло

\section{Резюме}

У неонкогенних клітинних лініях НВ2 і МСF10А ген ТР53 розташований всередині відносно невеликої петлі хроматину ( 50 тис. пар нуклеотидів), обмеженої двома ділянками прикріплення до ядерного матриксу (ДПМ). Мета. Проаналізувати хроматинові маркери Н4Ac і Н3К9те3 у зазначених ДПМ і Р1 промоторі гена ТР53 в різних клітинних лініях молочної залози. Методи. Імунопрецинітацію хроматину за допомогою антитіл проти маркерів активного хроматину Н4Ac і гетерохроматину Н3К9тез використано для характеристики стану хроматину елементів ДПМ у неонкогенних клітинних лініях НB2 і MCF10A та злоякісних клітинних лініях MCF-7, MDA-MB-231, БT-474 і T47D. Результати. Зазначені епігенетичні маркери нерівномірно розподілені в досліджуваних ДПМ для всіх проаналізованих ліній клітин молочної залози. Висновки. Не знайдено кореляиї в епігенетичному статусі ДПМ і хроматину. Це дозволяє припустити, щчо фіксація у ядерному матриксі і статус хроматину можуть бути незалежними. Суттєве збагачення Н3К9те3 P1 промоторної області гена ТР53 клітинної лінії MCF-7 може бути причиною нижчих рівнів експресії ТР53, описаних раніше нашою групою.

Ключові слова: ТР53, хроматин, петлевий домен, МАР, ракмолочної залози, епігенетичні модифікації гістонів, чип аналізу.

Обогащение хроматиновыми маркерами Н4Ac и Н3К9me3 домена гена TP53 в клеточных линиях молочной железы

Гю Дж. Р. Сантос, А. С. С. Гоес, К. В. де Моура Галло

Резюме

В неонкогенных клеточных линиях НВ2 и МСF10А ген ТP53 расположен внутри относительно небольшой петли хроматина ( 50 тыс. пар нуклеотидов), ограниченной двумя участками прикрепления к ядерному матриксу (УПМ). Цель. Проанализировать хроматиновые маркеры H4Aс и Н3К9те3 в указанных УПМ и Р1 промоторе гена ТР53 в различных клеточных линиях клетокмолочной железы. Методы. Иммунопреципитацию хроматина с помошью антител против маркеров активного хроматина Н4Ac и гетерохроматина Н3К9те3 использовали для характеристики состояния хроматина элементов УПМ в неонкогенных клеточных линиях НВ2 и МСF10А и злокачественных клеточных линиях MCF-7, MDA-MB-231, БT-474 и T47D. Результаты. Указанные эпигенетические маркеры неравномерно распределены в исследованных УПМдля всех анализируемых линий клетокмолочной железы. Выводы. Не выявлена корреляция в эпигенетическом статусе УПМ и хроматина. Это позволяет предположить, что фиксация в ядерном матриксе и статус хроматина могут быть независимыми. Сушественное обогашение Н3К9те3 P1 промоторной области гена ТР53 клеточной линии МCF-7 может быть причиной более низких уровней экспрессии ТР53, описанных ранее нашей группой.

Ключевые слова: ТР53, хроматин, петлевой домен, МАР, рак молочной железы, эпигенетические модификачии гистонов, чип анализа.

\section{REFERENCES}

1. Choe MK, Hong CP, Park J, Seo SH, Roh TY. Functional elements demarcated by histone modifications in breast cancer cells. Biochem Biophys Res Commun. 2012;418(3):475-82.

2. Budhavarapu VN, Chavez M, Tyler JK. How is epigenetic information maintained through DNA replication? Epigenetics Chromatin. 2013;6(1):32.

3. Terweij $M$, van Leeuwen $F$. Histone exchange: sculpting the epigепотею Front Life Sci. 2013; 7(1-2):63-79.

4. Luo XG, Guo S, Guo Y, Zhang CL. Histone modification and breast cancer. Breast cancer - focusing tumor microenvironment, stem cells and metastasis. Eds M Gunduz, E Gunduz. 2011; Ch. 15:321-342.

5. Chicoine LG, Schulman IG, Richman R, Cook RG, Allis CD. Nonrandom utilization of acetylation sites in histones isolated from Tetrahymena. Evidence for functionally distinct $\mathrm{H} 4$ acetylation sites. J Biol Chem. 1986;261(3):1071-6.

6. O'Neill LP, Turner BM. Histone $\mathrm{H} 4$ acetylation distinguishes coding regions of the human genome from heterochromatin in a differentiation-dependent but transcription-independent manner. EMBO J. 1995;14(16):3946-57.

7. Thorne AW, Kmiciek D, Mitchelson K, Sautiere P, CraneRobinson C. Patterns of histone acetylation. Eur J Biochem. 1990; 193 (3):701-13.

8. Leroy G, Dimaggio PA, Chan EY, Zee BM, Blanco MA, Bryant B, Flaniken IZ, Liu S, Kang Y, Trojer P, Garcia BA. A quantitative atlas of histone modification signatures from human cancer cells. Epigenetics Chromatin. 2013;6(1):20.

9. Bell O, Tiwari VK, Thoma NH, Schubeler D. Determinants and dynamics of genome accessibility. Nat Rev Genet. 2011;12(8): 554-64.

10. Hon GC, Hawkins RD, Caballero OL, Lo C, Lister R, Pelizzola $M$, Valsesia A, Ye Z, Kuan S, Edsall LE, Camargo AA, Stevenson $B J$, Ecker JR, Bafna V, Strausberg RL, Simpson AJ, Ren B. Global DNA hypomethylation coupled to repressive chromatin domain formation and gene silencing in breast cancer. Genome Res. 2012;22(2):246-58.

11. Baylin SB, Jones $P A$. A decade of exploring the cancer epigenome - biological and translational implications. Nat Rev Cancer. 2011;11(10):726-34.

12. Vassetzky YS, Hair A, Razin SV. Rearrangement of chromatin domains in cancer and development. J Cell Biochem Suppl. 2000;Suppl 35:54-60.

13. Razin SV, Iarovaia $O V$, Vassetzky YS. A requiem to the nuclear matrix: from a controversial concept to $3 \mathrm{D}$ organization of the nucleus. Chromosoma. 2014; 123(3):217-24

14. Eivazova ER, Gavrilov A, Pirozhkova I, Petrov A, Iarovaia OV, Razin SV, Lipinski M, Vassetzky YS. Interaction in vivo between the two matrix attachment regions flanking a single chromatin loop. J Mol Biol. 2009;386(4):929-37.

15. Razin SV, Vassetzky YS, Hancock R. Nuclear matrix attachment regions and topoisomerase II binding and reaction sites in the vicinity of a chicken DNA replication origin. Biochem Biophys Res Commun. 1991;177(1):265-70.

16. Ottaviani D, Lever E, Takousis P, Sheer D. Anchoring the genome. Genome Biol. 2008;9(1):201.

17. Wilson RH, Coverley D. Relationship between DNA replication and the nuclear matrix. Genes Cells. 2013 Jan;18(1):17-31.

18. Rivera-Mulia JC, Hernandez-Munoz R, Martinez F, Aranda-Anzaldo $A$. DNA moves sequentially towards the nuclear matrix during DNA replication in vivo. BMC Cell Biol. 2011;12:3. 
19. Bode J, Maass $K$. Chromatin domain surrounding the human interferon-beta gene as defined by scaffold-attached regions. Biochemistry. 1988;27(13):4706-11.

20. Forrester WC, Fernandez LA, Grosschedl R. Nuclear matrix attachment regions antagonize methylation-dependent repression of long-range enhancer-promoter interactions. Genes Dev. 1999; 13(22):3003-14.

21. Fernandez LA, Winkler M, Grosschedl R. Matrix attachment region-dependent function of the immunoglobulin mu enhancer involves histone acetylation at a distance without changes in enhancer occupancy. Mol Cell Biol. 2001;21(1):196-208.

22. Martens JH, Verlaan M, Kalkhoven E, Dorsman JC, Zantema A. Scaffold/matrix attachment region elements interact with a p300-scaffold attachment factor A complex and are bound by acetylated nucleosomes. Mol Cell Biol. 2002;22(8):2598-606.

23. Keaton MA, Taylor CM, Layer RM, Dutta A. Nuclear scaffold attachment sites within ENCODE regions associate with actively transcribed genes. PLoS One. 2011;6(3):e17912.

24. Kisseljova NP, Dmitriev P, Katargin A, Kim E, Ezerina D, Markozashvili D, Malysheva D, Planche E, Lemmers RJ, van der Maarel SM, Laoudj-Chenivesse D, Lipinski M, Vassetzky YS. DNA polymorphism and epigenetic marks modulate the affinity of a scaffold/matrix attachment region to the nuclear matrix. Eur $J$ Hum Genet. 2014 Jan 22. doi: 10.1038/ejhg.2013.306.

25. Hendzel MJ, Sun JM, Chen HY, Rattner JB, Davie JR. Histone acetyltransferase is associated with the nuclear matrix. $J$ Biol Chem. 1994;269(36):22894-901

26. Davie JR. Nuclear matrix, dynamic histone acetylation and transcriptionally active chromatin. Mol Biol Rep. 1997; 24 (3): 197-207.

27. Goes AC, Cappellen D, Santos GC Jr, Pirozhkova I, Lipinski M, Vassetzky Y, de Moura-Gallo CV. Loop domain organization of the p53 locus in normal and breast cancer cells correlates with the transcriptional status of the TP53 and the neighboring genes. $J$ Cell Biochem. 2011;112(8):2072-81.

28. Trevilla-Garcia C, Aranda-Anzaldo A. Cell-type-specific organization of nuclear DNA into structural looped domains. J Cell Biochem. 2011;112(2):531-40.
29. Dijkwel PA, Hamlin JL. Matrix attachment regions are positioned near replication initiation sites, genes, and an interamplicon junction in the amplified dihydrofolate reductase domain of Chinese hamster ovary cells. Mol Cell Biol. 1988;8(12): 5398-409.

30. Boulikas T. Chromatin domains and prediction of MAR sequences. Int Rev Cytol. 1995;162A:279-388.

31. Muller PA, Vousden KH. p53 mutations in cancer. Nat Cell Biol. 2013;15(1):2-8.

32. Khoury MP, Marcel V, Fernandes K, Diot A, Lane DP, Bourdon $J C$. Detecting and quantifying p53 isoforms at mRNA level in cell lines and tissues. Methods Mol Biol. 2013;962:1-14.

33. Wang B, Niu D, Lam TH, Xiao Z, Ren EC. Mapping the p53 transcriptome universe using p53 natural polymorphs. Cell Death Differ. 2014;21(4):521-32.

34. Razin SV, Petrov A, Hair A, Vassetzky YS. Chromatin domains and territories: flexibly rigid. Crit Rev Eukaryot Gene Expr. 2004;14(1-2):79-88.

35. Espinoza $C A$, Ren $B$. Mapping higher order structure of chromatin domains. Nat Genet. 2011;43(7):615-6.

36. van Steensel B. Chromatin: constructing the big picture. $E M B O$ J. 2011;30(10):1885-95.

37. Zuleger N, Robson MI, Schirmer EC. The nuclear envelope as a chromatin organizer. Nucleus. 2011;2(5):339-49.

38. Gargiulo $G$, Minucci $S$. Epigenomic profiling of cancer cells. Int J Biochem Cell Biol. 2009;41(1):127-35.

39. Dalvai $M$, Bystricky $K$. The role of histone modifications and variants in regulating gene expression in breast cancer. J Mammary Gland Biol Neoplasia. 2010;15(1):19-33.

40. Majocchi S, Aritonovska E, Mermod N. Epigenetic regulatory elements associate with specific histone modifications to prevent silencing of telomeric genes. Nucleic Acids Res. 2014;42(1): 193-204.

Received 30.02.14 